\title{
PEMBERDAYAAN PEREMPUAN BALI DALAM MEMBUAT UPAKARA DI BANJAR GEMEH
}

\author{
Made Novia Indriani \\ Civil Engineering, Hindu Indonesia University, Jln. Sangalangit, Denpasar, Indonesia \\ madenovia@gmail.com
}

\begin{abstract}
ABSTRAK
Perempuan di Bali dituntut banyak menguasai hal yang berkaitan dengan prosesi ritual, persembahyangan, adat dan budaya serta prosesi upacara adat sesuai tata cara Hindu. Salah satu yang wajib perempuan Hindu di Bali kuasai adalah mejejaitan, yang merupakan tahapan kegiatan dalam membuat upakara banten. Upakara atau banten tersebut sebagai sarana untuk berhubungan/mendekatkan diri dengan Ida Sang Hyang Widhi Wasa/manifestasi-Nya yang akan dihadirkan dalam ritual persembahyangan. Pemberdayaan perempuan Bali dalam membuat upakara di Br. Gemeh ini, juga mampu mewujudkan fungsi-fungsi banjar adat baik di bidang agama, adat, budaya, sosial dan ekonomi.
\end{abstract}

\section{Kata kunci : Pemberdayaan, perempuan bali, upakara, banjar}

\section{PENDAHULUAN}

\section{Pemberdayaan}

Pemberdayaan masyarakat adalah proses pembangunan di mana masyarakat berinisiatif untuk memulai proses kegiatan sosial untuk memperbaiki situasi dan kondisi diri sendiri. Pemberdayaan masyarakat hanya bisa terjadi apabila masyarakat itu sendiri ikut pula berpartisipasi. Pemberdayaan adalah upaya untuk membangun kemampuan masyarakat, dengan mendorong, memotivasi, membangkitkan kesadaran akan potensi yang dimiliki dan berupaya untuk mengembangkan otensi itu menjadi tindakan nyata https://id.wikipedia.org > wiki > Pemberdayaan_masyarakat. Dari beberapa pernyataan tentang pengertian pemberdayaan, dapat disimpulkan bahwa pemberdayaan adalah suatu upaya yang dilakukan oleh seseorang maupun kelompok melalui berbagai kegiatan pemberian ketrampilan, pengembangan pengetahuan, penguatan kemampuan atau potensi yang mendukung agar dapat terciptanya kemandirian, dan keberdayaan pada masyarakat baik itu dari segi ekonomi, sosial, budaya, maupun pendidikan untuk membantu memecahkan berbagai masalah-masalah yang dihadapi.

Salah satu adat yang masih dipertahankan dan diterapkan di Bali adalah penerapan banjar adat atau banjar suka duka. Banjar suka duka mengikat anggotanya berdasarkan persamaan adat dan tradisi kebudayaan yang bertujuan untuk meningkatkan kebersamaan umat dalam menjalankan segala kegiatan dalam suka maupun duka (Wihantari, 2013). Banjar suka duka masih bisa bertahan sampai sekarang ini karena mempunyai beberapa fungsi yaitu fungsi di bidang agama; fungsi dibidang adat, sosial, dan budaya; dan fungsi di bidang ekonomi, keamanan, dan politik/pemerintahan (Noviasi,Waleleng, \& Tampi, 2015). Kastama (2013) menjelaskan bahwa prinsip yang paling penting dalam ikatan kesadaran sosial di tingkat banjar ini adalah suka duka. Prinsip inilah yang merupakan landasan utama untuk mengaktifkan keseluruhan kegiatan yang terdapat didalamnya.

\section{Perempuan Bali}


Perempuan di Bali memang dituntut banyak menguasai hal yang berkaitan dengan prosesi ritual, persembahyangan, adat dan budaya serta prosesi upacara adat sesuai tata cara Hindu. Salah satu yang wajib perempuan kuasai adalah "mejejaitan". Mejejaitan adalah membuat berbagai sarana persembahyangan yang terbuat dari daun kelapa atau janur, daun ental dengan berbagai pendukungnya seperti bunga dan buah. Mejejaitan artinya menjahit bahan seperti janur untuk dibuat wadah atau sarana persembahyangan untuk membuat banten atau sesaji, juga menjahit janur untuk perlengkapan lain dalam ritual upacara maupun saat hari raya. https://www.kompas.com/

Dalam teori sosial Parson, peran didefinisikan sebagai harapan-harapan yang diorganisasi terkait dengan konteks interaksi tertentu yang membentuk orientasi motivasional individu terhadap yang lain. Melalui pola-pola kultural, maka orang belajar siapa mereka di depan orang lain dan bagaimana mereka harus bertindak terhadap orang lain (John Scott, 2011:228). Peran penting dari pemahaman sosiologi, karena mendemonstrasikan bagaimana aktivitas individu dipengaruhi secara sosial dan mengikuti pola-pola tertentu. Para sosiolog telah menggunakan peran sebagai unit untuk menyusun kerangka intitusi sosial.

Perempuan bali bukan saja berperan sebagai ibu dan mengurus rumah tangga, namun berperan dalam kegiatan keagamaan, sosial masyarakat ,dan kesehatan. Seperti yang terdapat di beberapa Banjar Adat di Kota Denpasar, dimana perempuan bali mengaktualisasikan dirinya dalam menerapkan nilai-nilai harmonisasi dalam kehidupan bermasyarakat di era globalisasi saat ini. Aktualisasi diri perempuan bali dengan banjar adat sebagai "tempat" atau wadah dalam melakukan berbagai macam kegiatan,mampu mewujudkan fungsi-fungsi banjar adat baik di bidang agama, adat, budaya, sosial dan ekonomi. Namun kegiatan perempuan bali tidak mendominasi pada fungsi banjar adat dalam bidang keamanan dan politik serta pemerintahan. Kegiatan-kegiatan yang dilakukan perempuan bali (ibu-ibu PKK dan ibu-ibu lansia) tersebut dilakukan sebagai wujud bhakti kehadapan Ida Sanghyang Widhi Wasa, mewujudkan keharmonisan hubungan manusia dengan Tuhan. Kegiatan tersebut dilakukan pula sebagai bentuk toleransi hubungan (suka dan duka) personal dengan masyarakat, sehingga mampu mewujudkan keharmonisan hubungan manusia dengan manusia, serta hubungan manusia dengan alam/lingkungannya, yang diwujudkan oleh perempuan bali (Indriani, MN 2019).

\section{Banjar}

Banjar adat dengan sistem kekerabatan dan budaya gotong royong yang khas kini menjelma menjadi lembaga tradisional yang sarat akan nilai-nilai agama, adat, seni dan budaya. Lembaga tradisional khususnya banjar adat penting dipahami fungsi dan peranannya karena merupakan salah satu unsur penunjang keberlangsungan kehidupan masyarakat Bali yang selaras dan harmonis.

Fungsi Banjar Adat di Bidang Agama ; lembaga atau organisasi sosial tradisional Bali yang bersifat umum seperti banjar adat sesungguhnya berlandaskan ajaran agama Hindu dan kearifan lokal budaya Bali, sehingga di dalamnya terkandung nilai-nilai spiritual, estetika, dan solidaritas (Pitana, 1994:158). Dalam hal ini, agama termasuk ritual di dalamnya sebagai salah satu bentuk perilaku manusia yang telah terlembaga, adalah bagian dari keseluruhan sistem sosial, dan berfungsi bagi masyarakat khususnya sebagai pengintegrasi. Maka dari pandangan fungsionalis, lembaga adat sekaligus berfungsi untuk meningkatkan religiusitas dalam rangka mempertahankan keseimbangan seluruh sistem sosial (Hadi, 2006:57). Sejalan dengan itu maka setiap banjar adat wajib untuk ngayah (pelayanan) saat ada persembahyangan kegamaan di Pura Tri Kahyangan Desa selama setahun penuh, secara bergiliran. Saat ngayah, seluruh 
anggota banjar adat baik pria maupun wanita akan meluangkan waktu untuk dapat mempersiapkan segala sarana dan prasarana yang dibutuhkan dalam pelaksanaan persembahyangan nantinya. Banjar adat wajib mempersiapkan segala sesuatu yang diperlukan dalam perayaan tersebut sejak beberapa hari sebelumnya sampai pada hari $\mathrm{H}$. Banjar adat menjadi media yang cukup efektif bagi pengembangan spiritual, seperti belajar membuat banten (sarana sesajen).

\section{Upakara}

Upakara adalah bentuk pelayanan yang diwujudkan dari hasil kegiatan kerja berupa materi yang dipersembahkan atau dikurbankan dalam suatu upacara keagamaan. Sedangkan Upacara adalah gerakan sekeliling kehidupan manusia dalam upaya menghubungkan diri dengan Hyang Widhi Wasa / Tuhan Yang Maha Esa.

Upakara sering dikenal dengan sebutan banten, upakara berasal dari kata "Upa" dan "Kara", yaitu Upa berarti berhubungan dengan, sedangkan Kara berarti perbuatan/pekerjaan (tangan). Upakara merupakan bentuk pelayanan yang diwujudkan dari hasil kegiatan kerja berupa materi yang dipersembahkan atau dikurbankan dalam suatu upacara keagamaan. Dalam kehidupan agama Hindu di Bali, setiap pelaksanaan upacara keagamaan selalu mempergunakan upakara atau banten sebagai sarana untuk berhubungan/mendekatkan diri dengan pujaannya yaitu Ida Sang Hyang Widhi Wasa/manifestasi-Nya yang akan dihadirkan.

Upakara atau banten tersebut dibuat dari berbagai jenis materi atau bahan-bahan yang ada, kemudian ditata dan diatur sedemikian rupa sehingga berwujud aturan atau persembahan yang indah dilihat, mempunyai fungsi simbolis dan makna filosofis keagamaan yang mendalam. Dalam pustaka Bhagawadgita Bab IX sloka 26 menyebutkan tentang unsur-unsur pokok persemambahan itu adalah :

Patram Puspam phalam to yam yo me bhaktya prayacchati tad aham bhaktyupahrtam asnami prayatatmanah

Artinya :

Siapapun yang dengan kesujudan mempersembahkan pada Ku daun, bunga, buah-buahan atau air, persembahan yang didasari oleh cinta dan keluar dari hati suci, Aku terima sebagai bhakti persembahan dari orang yang berhati suci.

Dari sloka diatas dapat dilihat hal-hal sebagai berikut :

1. Daun; dapat berupa janur, ron, tlujungan/daun pisang dan daun yang lainnya yang disebut dengan plawa, sirih, daun pilasa dan sebagainya.

2. Buah; dapat berupa buah-buahan seperti : kelapa, padi,tingkih,pangi,pinang,pisang, jenis kacang-kacangan serta semua jenis buah-buahan yang dapat dimakan.

3. Bunga; dapat berupa segala bentuk dan jenis bunga-bungaan yang harum, segar dan yang ditetapkan dan diperkenankan untuk banten.

4. Air; berupa zat cair seperti : air untuk pembersihan segala sarana banten, air kelapa, arakberem-tuak, madu, empehan/susu, air kumkuman dan lainnya.

5. Api/Gni; yang berfungsi sebagai pembakar sarana upakara berupa kemenyan, majagau,serbuk kayu-kayuan seperti cendana,dupa,lilin, dan lainnya.

Mengenai bahan-bahan upakara untuk persembahan atau korban suci tersebut, semuanya diambil dari ciptaan Ida Hyang Widhi Wasa di dunia ini dan kesemuanya itu dapat dibedakan menjadi tiga jenis, yaitu :

1. Mataya, adalah sesuatu yang tumbuh. Bahan-bahan ini terdiri dari tumbuh-tumbuhan yang dipakai sarana upakara terdiri dari berbagai jenis daun,bunga dan buah-buahan. 
2. Mantiga, adalah sesuatu yang lahir dua kali seperti telur itik, ayam, angsa dan lainnya.

3. Maharya, adalah sesuatu yang lahir sekali langsung menjadi binatang, seperti binatangbinatang berkaki empat misalnya sapi,babi,kerbau dan lain sejenisnya.

Upakara memiliki fungsi antara lain :

1. Sebagai alat konsentrasi

Upakara sebagai alat konsentrasi, hal ini disebabkan oleh kemampuan yang dimiliki oleh manusia sangat terbatas adanya, dalam usaha untuk mendekatkan hubungan dengan Ida Sang Hyang Widhi Wasa dan segala manifestasi-Nya, untuk menyampaikan rasa terima kasih karena berbagai anugrah yang diberikan. Dengan melihat banten/upakara, pikirannya sudah teringat dan terarah pada yang dihadirkan atau dipuja. Penggunaan upakara sebagai alat konsentrasi, umumnya dilakukan oleh mereka yang menempuh jalan melalui bhakti marga dan karma marga dalam ajaran catur marga. Bagi bhakti marga mengutamakan penyerahan diri dan pencurahan rasa yang didasari dengan cinta kasih terhadap yang dipuja yaitu Ida Hyang Widi Wasa dan segala menifestasi-Nya, untuk mencapai kebahagiaan yang tertinggi. Bagi karma marga, menekankan rasa bhaktinya pada pengabdian yang berwujud kerja tanpa pamrih. Kerja merupakan simbol hidup, hidup adalah untuk beryadnya, karena melalui yadnyalah semua yang hidup di dunia ini diciptakan oleh Ida Hyang Widhi Wasa pada jaman dahulu. Hidup manusia dibelenggu oleh kerja, seperti dinyatakan dalam pustaka suci Bhagawadgita sebagai berikut :

“yajnarthat karmano' nyatra lako'yam karma bandhanah adhartham karma kaunteya mukta sangah samachara (III.9)

Artinya : Kecuali untuk tujuan berbakti, dunia ini dibelenggu oleh hukum kerja, karenanya bekerjalah demi bhakti, tanpa kepentingan pribadi, oh Kuntipura.

2 Upakara sebagai persembahan atau kurban suci

Upakara sebagai persembahan, apabila ditujukan kehadapan yang lebih tinggi tingkatannya dari manusia. Disebut kurban suci apabila ditujukan kepada yang tingkatannya lebih rendah daripada manusia seperti dalam pelaksanaan upacara bhuta yadnya. Maksud dan tujuan dari persembahan atau korban suci itu adalah sebagai pernyataan dari perwujudan rasa terima kasih manusia kehadapan Ida Hyang Widhi Wasa dan segala manifestasi-Nya. Sebagai contoh yang paling sederhana adalah yadnya sesa yaitu persembahan yang dilakukan setiap hari setelah selesai memasak. Mengenai tempat dan dasar sastra dari yadnya sesa adalah ada disebutkan pada Manawa Dharma Sastra III. 68-69 sebagai berikut :

Panca suna grhastasya culli pesanyu paskarah, kandani codakumhasca badhyate yastu vahayan. Tasam kramena sarvasam niskrtyartham mahasibhih, panca klpta mahayajnah pratyaham grhamedhinam.

Artinya : Seorang Kepala Keluarga mempunyai lima macam tempat penyembelihan yaitu tempat masak, batu pengasah, sapu, lesung, dengan alunya, tempayan tempat tempat air dengan pemakaian mana Ia diikat oleh belenggu dosa. Untuk menebus dosanya yang ditimbulkan oleh pemakaian kelima alat itu,para Maha Rsi telah menggariskan untuk Kepala Keluarga agar setiap harinya melakukan Panca Yadnya.

3 Upakara sebagai sarana pendidikan memuja Ida Hyang Widhi Wasa.

Upakara yang telah dapat diwujudkan, merupakan hasil dari pengendalian diri terhadap keterikatan akan benda-benda duniawi. Bila hal itu dihayati lebih mendalam, maka mereka yang telah berhasil membuat upakara untuk diyadnyakan, itu berarti ,mereka telah berhasil 
menyucikan pikirannya dari rasa ego terhadap karunia Ida Hyang Widhi Wasa yang telah menjadi miliknya. Rasa rela dan rasa tulus ikhlas telah diamalkan, sekaligus perbuatan yang demikian itu telah termasuk dalam upaya penyucian diri secara lahiriah dijiwai dengan rasa bathiniah. Usaha untuk membebaskan diri dari keterikatan pada hawa nafsu guna mencapai kesucian secara lahir dan bathin, sangat diperlukan untuk mendekatkan diri kehadapan Ida Hyang Widhi Wasa, sebagaimana yang telah dinyatakan dalam pustaka suci Bhagawadgita sebagai berikut :

"Vita raga bhaya krodha manmaya mam upasritah bahavo jnanam pasa puta madbhavam agatah (IV.10)

Artinya : Terbatas dari hawa nafsu, takut dan benci bersatu dan berlindung pada$\mathrm{ku}$ dibersihkan oleh kesucian budi pekerti banyak yang telah mencapai diri-ku

4 Upakara sebagai perwujudan Ida Hyang Widhi Wasa dalam berbagai manifestasi.bsuci yaitu rontal "Yadnya Prakerti,Tegesing Arti Bebantenan", semua sarana yang dipakai mempunyai arti simbolis, seperti contoh upakara yang paling sederhana yaitu canang, didalam canang itu terdapat daun kayumas (plawa), bunga, dan porosan. Semua itu arti tersendiri, seperti plawa, disebutkan dalam Lontar Yadnya Prakerti bahwa Plawa adalah lambang pertumbuhan pikiran yang hening dan suci. Dalam proses pelaksanaan pemujaan terhadap Tuhan/Hyang Widhi, sangat wajib hukumnya dilakukan dengan pikiran yang hening dan suci dan atas dasar hati yang tulus ikhlas dengan tanpa berharap akan pahala, karena semua yang dilakukan ini merupakan suatu kewajiban atas ciptaan-Nya. Dalam Bhagawadgita II. 51 disebutkan sebagai berikut :

Karma-jam budhi-yukta hi phalam tyaktva manisinah, janma-bandha-vinirmuktah padam gacchanty anamayam.

Artinya : Bagi orang bijaksana, yang pikirannya bersatu dengan Yang Maha Tahu, tidak ,mengharap akan hasil dari perbuatannya (sebagai motif), akan tetapi bebas dari perbuatannya karma dan mencapai tempat dimana tak ada penderitaaan.

\section{PEMBAHASAN}

Perempuan Bali yang saat ini sudah setara dengan pria sudah banyak yang sibuk menjadi wanita karir sehingga selalu perhitungan waktu. Diharapkan melalui pelatihan membuat upakara banten, perempuan Bali mampu membuat upakara banten sendiri atau juga dapat membuka peluang bisnis untuk menambah penghasilan keluarga mengingat di Bali setiap saat terdapat upacara keagamaan yang membutuhkan berbagai sarana dan prasarana persembahyangan.

Berbagai macam jenis banten, diajarkan ke ibu-ibu warga banjar adat Gemeh dari cara mejejaitan hingga metandingnya, yaitu antara lain :

a. Banten caru eka sata

b. Bayakawonan

c. Canang sari

d. Daksina

e. Pejati

f. Pesucian

g. Prayascita

h. Banten suci

i. Sambutan 
Adapun uraian mengenai salah satu jenis banten yang diajarkan saat pelatihan membuat banten di Banjar Gemeh yaitu membuat upakata banten caru eka sata sebagai berikut :

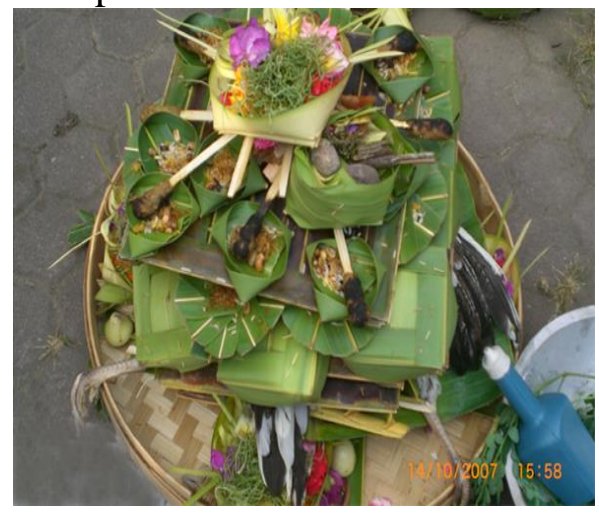

Gambar 2.1 Banten caru eka sata

Sumber : Pelatihan banten Br.Gemeh

Upakara Caru adalah salah satu dari bagian upakara Bhuta Yadnya, sebagai salah satu sarana untuk melaksanakan Sradha dan Bhakti umau Hindhu, khususnya umat Hindhu di Bali.

Makna dan fungsi upakara Caru :

1. Sebagai penetralisirkekuatan-kekuatanalam yang bersifat buruk, yg dapat menghilangkan keseimbangan hidup antara manusia dengan alam disekitarnya, sehingga muncul dimuka bumi bermacam-macam kejadian yang dapat menyengsarakan kehidupan manusia.

2. Sebagai sarana bahasa pengantar dari atmanastuti umat Hindhu di Bali, sehingga umat Hindhu di Bali dapat terhindar dari kategori kafir (sebagai simbul bahasa Weda).

3. Sebagai sarana Penyucian pada Tri Bhuwana ini sehingga proses ekosistem alam ini dapat lestari, seimbang dan berkesinambungan.

4. Sebagai sarana penyupatan terhadap makhluk-makhluk lain, agar makhluk yang disupat dapat meningkatkan kwalitas hidupnya pada kehidupannya dimasa mendatang.

5. Sebagai sarana peleburan dosa-dosa umatnya, karena mendapat kesempatan untuk berbuat kebajikan melalui berkorban suci.

6. Sebagai sarana untuk memohon restu kehadapan Sang Hyang Widhi atas apa yang dimakan oleh umatnya adalah atas Ciptaan Beliau.

Pembuatan upakara Caru ini adalah berdasarkan atas konsep "Tri Matra", yaitu :

1. Bhuta Matra adalah melaksanakan proses keharmonisan di alam semesta ini, salah satunya melalui pelaksanaan upacara pecaruan.

2. Prana Matra melaksanakan proses keharmonisan pada alam prana (embang), salah satunya melalui pelaksanaan upacara pecaruan.

3. Pradnya Matra melaksanakan proses keharmonisan pada alam luar angkasa (langit), salah satunya melalui pelaksanaan upacara pecaruan (lontar Aji Somya Mandhala).

Dengan demikian maka alas dari olah-olahan carunya adalah memakai Sengkuwi dengan anyaman/ulatan daun kelapa tua (slepan), pelepahnya 9 helai sebagai simbul Bhuta Matra, dan letaknya pada upakara caru tersusun dari bawah. Sengkuwi dengan pelepah 9 helai ini, dalam tetandingan disebut "Pajegan", berisi tetandingan lawar sebagai berikut : 
1. Lawar Merah, diletakkan di bagian kanan dari yang metanding, adalah sebagai simbul kekuatan "Kala".

2. Lawar Hijau, diletakkan di bagian kiri, sebagai simbul kekuatan "Butha".

3. Lawar Putih, diletakkan diatas, antara lawar merah dengan hijau, adalah sebagai simbul kekuatan "Durga".

Tetandingan ini adalah tetandingan yang disebut Tri Kona (memakai sarana binatang ayam). Perhitungan sate pajegan nya adalah sebagai berikut, memakai 3 jenis sate, yaitu :

a. sate lembat : simbul kala

b. sate calon : simbul butha

c. sate serapah : simbul durga.

Simbolis banten caru

a. Kelabang dangap-dangap

b. Sanggah cucuk

c. Alat-alat pecaruan: prakpak, tulud, sampat, kulkul

d. Penimpug

e. Sengkui

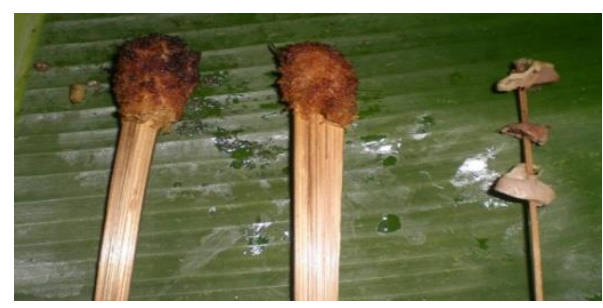

Gambar 2.2 Sate Caru

Sumber : Pelatihan banten Br.Gemeh

Keterangan sate caru, dari kiri ke kanan :

a. sate calon : simbul butha

b. sate lembat : simbul kala

c. sate serapah : simbul durga.

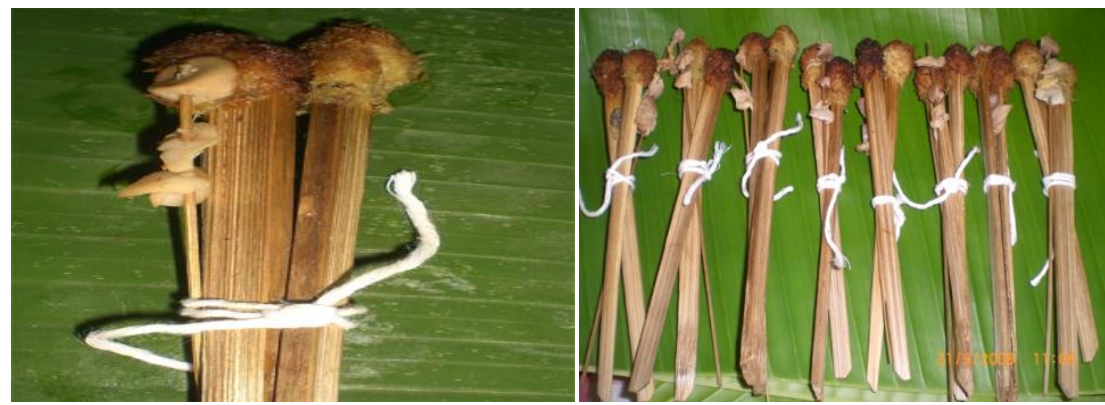

Gambar 2.3 Sate pajegan : 3 jenis sate (sate lembat, sate calon, sate serapah), diikat jadi satu.Untuk caru ayam brumbun, memerlukan 8 buah sate pajegan, (sesuai urip).

Sumber : Pelatihan banten Br.Gemeh 
Jurnal Sewaka Bhakti

Lembaga Penelitian dan Pengabdian Kepada Masyarakat

Universitas Hindu Indonesia Denpasar

Volume 3, Nomor 1 Oktober 2019

ISSN: 2654-2935 (Online)

https://ejournal.unhi.ac.id/index.php/sewakabhakti

pp.10-24
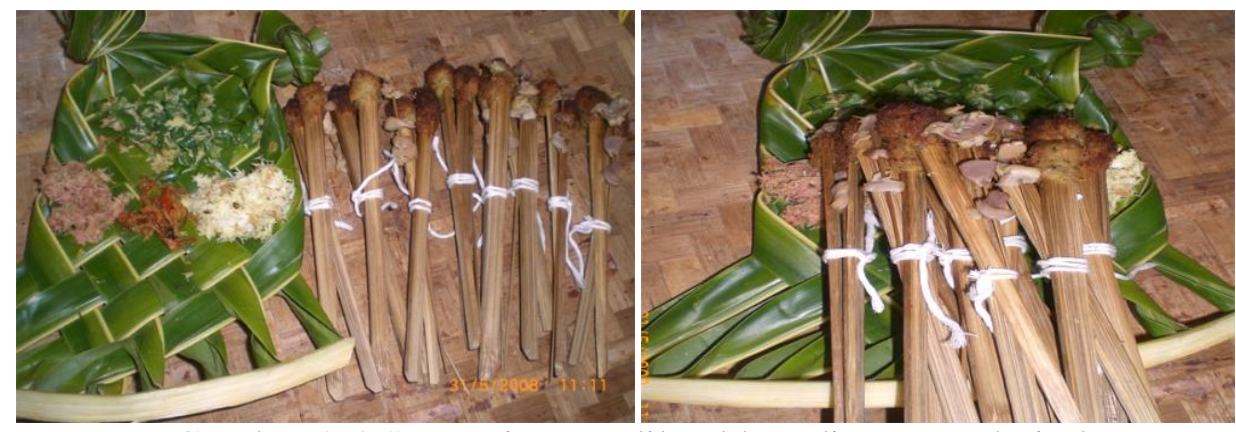

Gambar 2.4 Sate pajegan : diletakkan diatas sengkui ulatan 9.

Sumber : Pelatihan banten Br.Gemeh
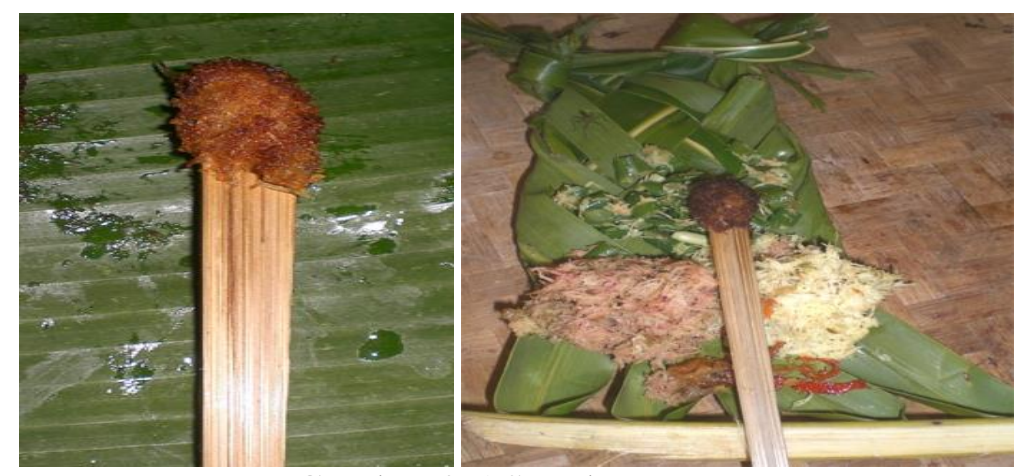

Gambar 2.5 Sate ketengan

Memakai sate lembat 1 katih, diletakkan diatas sengkui ulatan 5.

Sumber : Pelatihan banten Br.Gemeh

Adapun tetandingan banten caru eka sata ( ayam brumbun), sebagai berikut :

Taled 1

- $\quad$ porosan, pelas, bantal, tape, tebu, biyu

- Jaja raka-raka jangkep

- untek putih 5 bh

- $\quad$ rerasmen jangkep

- sampian pusung.

Taled 2

- Porosan, pelas, bantal, tape, tebu, biyu

- Jaja raka-raka jangkep

- untek merah 9 bh

- rerasmen jangkep

- sampian pusung. 
Jurnal Sewaka Bhakti

Lembaga Penelitian dan Pengabdian Kepada Masyarakat

Universitas Hindu Indonesia Denpasar

Volume 3, Nomor 1 Oktober 2019

ISSN: 2654-2935 (Online)

https://ejournal.unhi.ac.id/index.php/sewakabhakti

pp.10-24
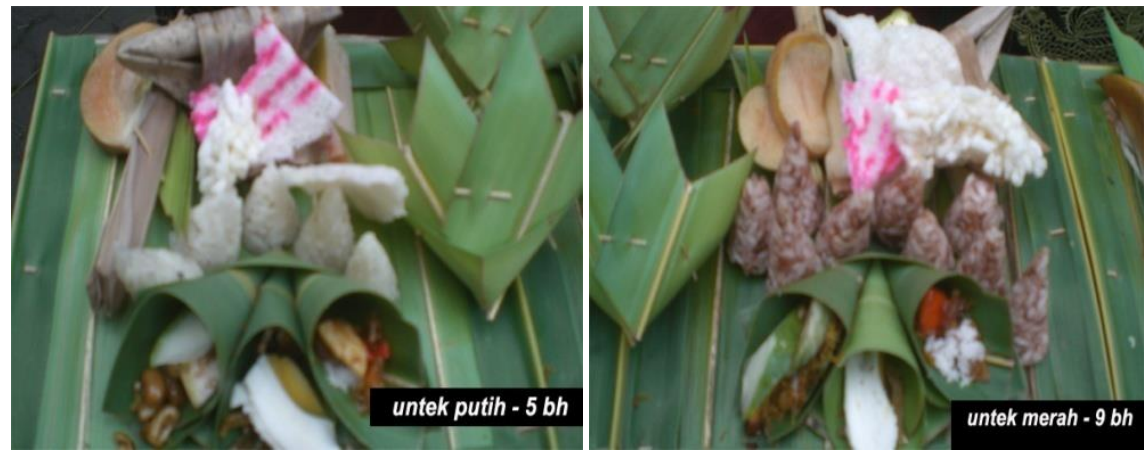

Gambar 2.6 Tetandingan caru taled 1 dan taled 2

Sumber : Pelatihan banten Br.Gemeh

Taled 3

- Diisi porosan, pelas, bantal, tape, tebu, biyu

- Jaja raka-raka jangkep

- $\quad$ untek kuning 7 bh

- rerasmen jangkep

- sampian pusung.

Taled 4

- Diisi porosan, pelas, bantal, tape, tebu, biyu

- Jaja raka-raka jangkep

- untek selem 4 bh

- rerasmen jangkep

- $\quad$ sampian pusung.

Taled 5
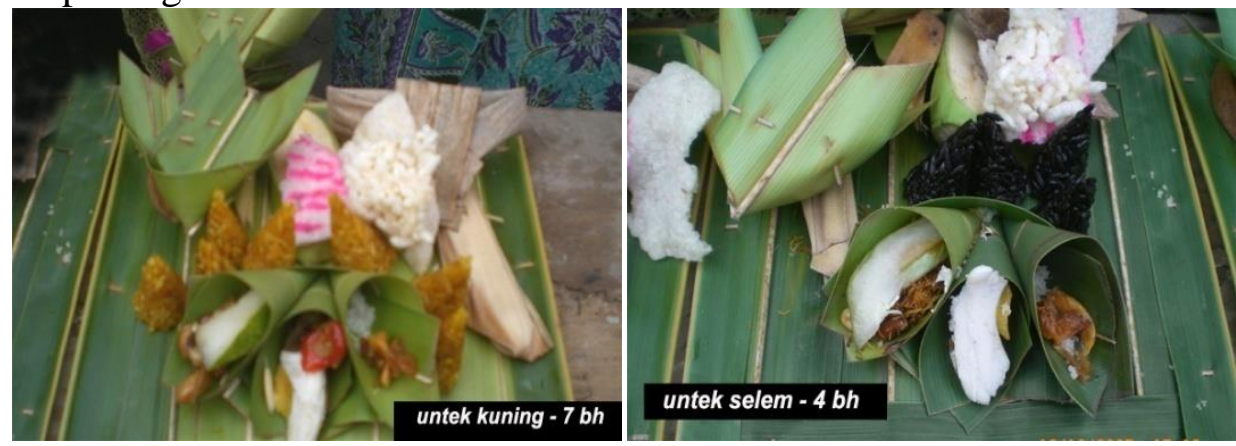

Gambar 2.7 Tetandingan caru taled 3 dan taled 4

Sumber : Pelatihan banten Br.Gemeh

- Diisi porosan, pelas, bantal, tape, tebu, biyu

- Jaja raka-raka jangkep

- untek brumbun 8 bh

- rerasmen jangkep

- $\quad$ sampian pusung.

Setelah itu, letakkan tetandingan tersebut dalam ngiu sesuai arah mata angin.

- atas / timur : untek putih (5)

- kanan/selatan : untek merah (9)

- bawah/barat : untek kuning (7) 
Jurnal Sewaka Bhakti

Lembaga Penelitian dan Pengabdian Kepada Masyarakat

Universitas Hindu Indonesia Denpasar

Volume 3, Nomor 1 Oktober 2019

ISSN: 2654-2935 (Online)

https://ejournal.unhi.ac.id/index.php/sewakabhakti

pp.10-24

- kiri/utara : : untek selem (4)

- Ditengah : untek brumbun (8)

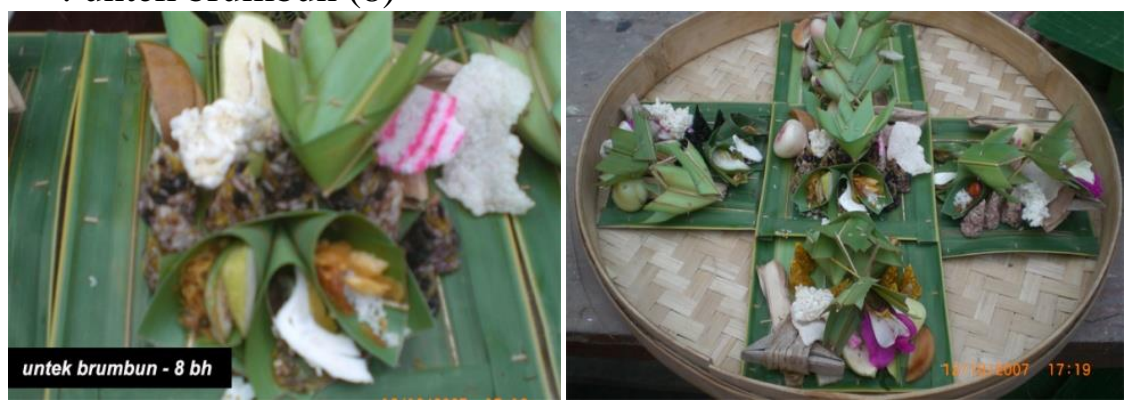

Gambar 2.8 Tetandingan caru taled 5 dan tetandingan dalam ngiu sesuai arah mata angin Sumber : Pelatihan banten Br.Gemeh
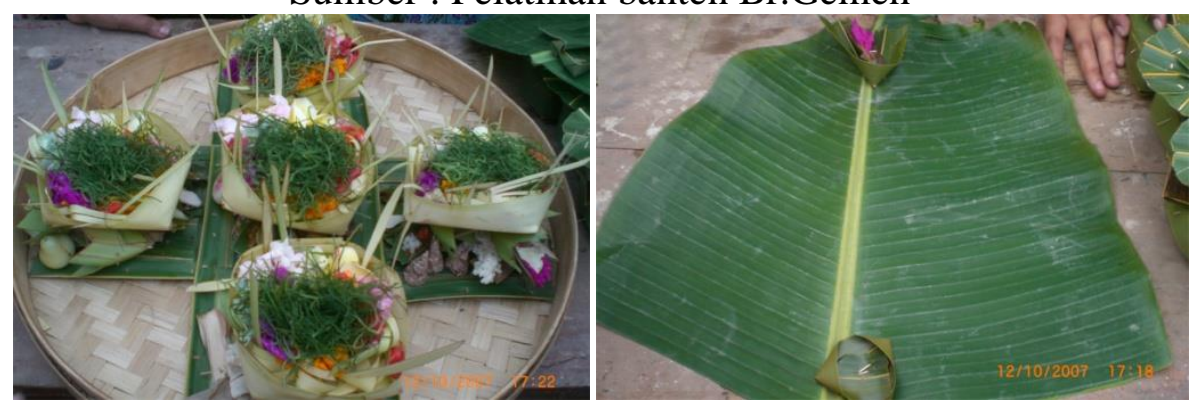

Gambar 2.8 Kemudian Diatasnya disusuni canang, Ambil daun telujungan biu udang saba. Diatas/ujung daun diisi sampian plaus, dan bagian bawah diisi celemik.

Sumber : Pelatihan banten Br.Gemeh
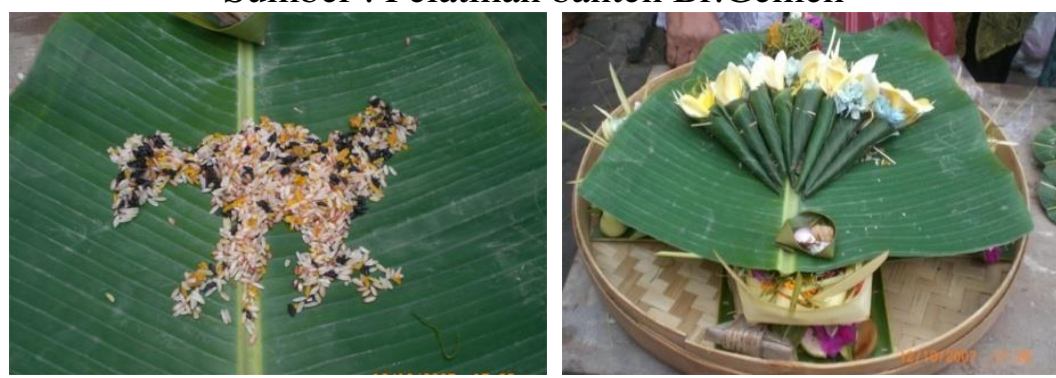

Gambar 2.9 Diatas daun telujungan, diisi nasi sasah Brumbun, kemudian direka berbentuk ayam. Diatas nasi re-rekan ayam ini, diisi kuangen 8 bh (sesuai urip), ditusuk, diletakkan di atas nasi rerekan. Celemik diisi bawang, jahe, garam

Sumber : Pelatihan banten Br.Gemeh

Sengkui untuk olahan carunya, dipakai sengkui :

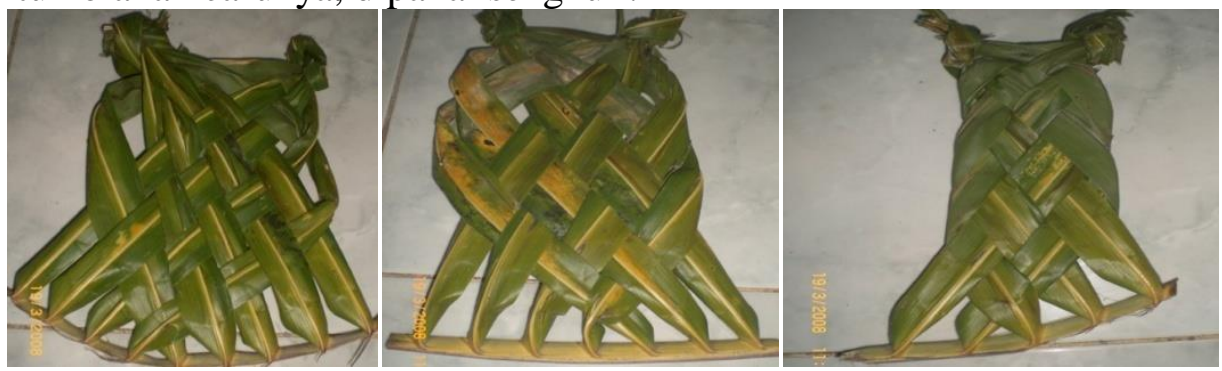

Gambar 2.10 Sengkui 
Jurnal Sewaka Bhakti

Lembaga Penelitian dan Pengabdian Kepada Masyarakat

Universitas Hindu Indonesia Denpasar

Volume 3, Nomor 1 Oktober 2019

ISSN: 2654-2935 (Online)

https://ejournal.unhi.ac.id/index.php/sewakabhakti

pp.10-24

\section{Sumber : Pelatihan banten Br.Gemeh}

- ulatan 9 helai sebagai simbul Bhuta Matra

- ulatan 7 helai sebagai simbul Pradnya Matra

- ulatan 5 helai sebagai simbul Prana Matra

Diatas sengkui diisi lawar dengan susunan sbb :

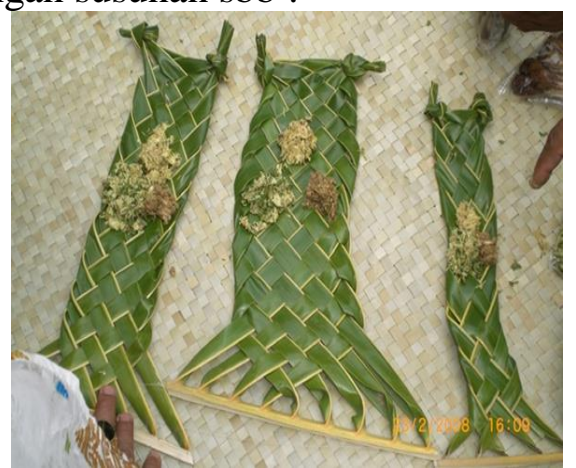

Gambar 2.11 Tandingan lawar pada sengkui

Sumber : Pelatihan banten Br.Gemeh

$\begin{array}{lll}\text { - } & \text { atas } & \text { : lawar putih simbul kekuatanm "durga". } \\ \text { - } & \text { kanan } & \text { : lawar barak simbul kekuatan "kala" } \\ \text { - } & \text { kiri } & \text { : lawar gadang simbul kekuatan "butha" } \\ \text { - } & \text { Bawah } & \text { : sambel }\end{array}$
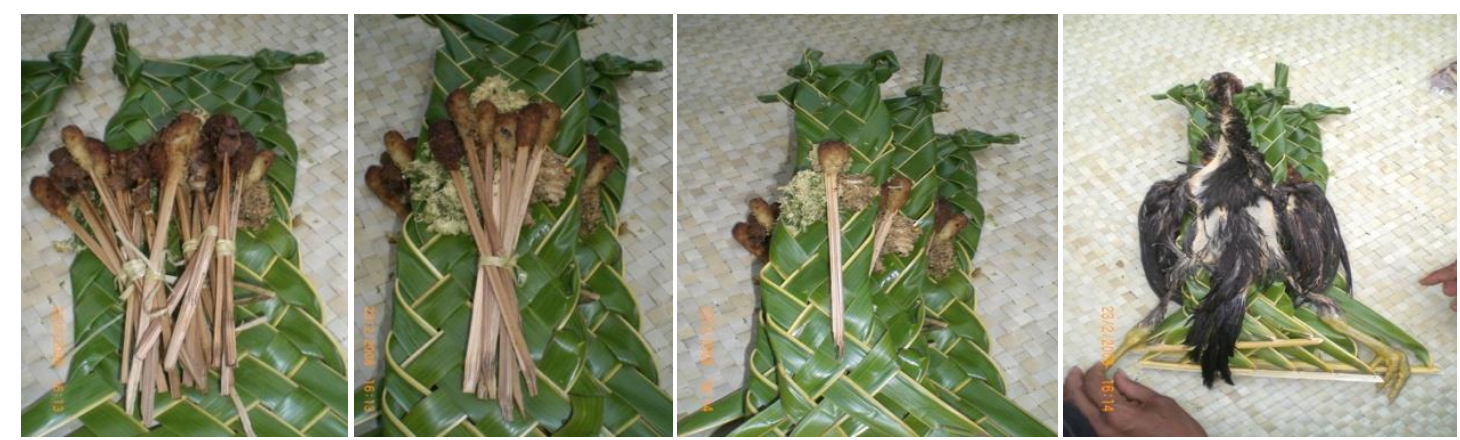

Gambar 2.12 Tetandingan pada sengkui (1)

Sumber : Pelatihan banten Br.Gemeh

Sate pajegan : 3 jenis sate diikat jadi satu (sate lembat, sate calon, sate serapah)

Sengkui ulatan 9 diletakkan paling bawah, diisi sate 8 ikat sate pajegan $(8 \times 3=24)$---- (1 ikat berisi 3 jenis sate, di sebut : pajegan).

diatasnya, disusuni sengkui ulatan 7 , diisi sate 1 jenis yaitu sate lembat sebanyak 8 katih (sesuai urip), disebut : bayuhan paling diatas, diletakkan sengkui ulatan 5, diisi sate lembat, 1 bh. disebut : ketengan.

kemudian diatas sengkui yang berisi ketengan ini, ditutup dengan belulang siap brumbun. 
Jurnal Sewaka Bhakti

Lembaga Penelitian dan Pengabdian Kepada Masyarakat

Universitas Hindu Indonesia Denpasar

Volume 3, Nomor 1 Oktober 2019

ISSN: 2654-2935 (Online)

https://ejournal.unhi.ac.id/index.php/sewakabhakti

pp.10-24

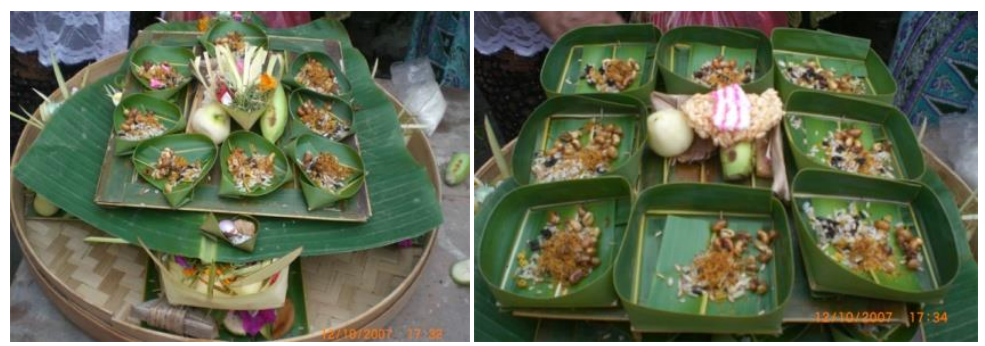

Gambar 2.13 Tetandingan pada sengkui (2)

Sumber : Pelatihan banten Br.Gemeh

- Ambil taledan yang berisi tangkih 8; masing-masing tangkih diisi nasi sasah brumbun + kacang saur.

- Pada bagian tengah taledan diisi jaja raka-raka jangkep dan sampian plaus.

- Ambil taledan yang berisi keben-kebenan; masing-masing diisi nasi sasah brumbun + kacang saur.

- $\quad$ Pada bagian tengah diisi jaja raka-raka jangkep dan sampian plaus.
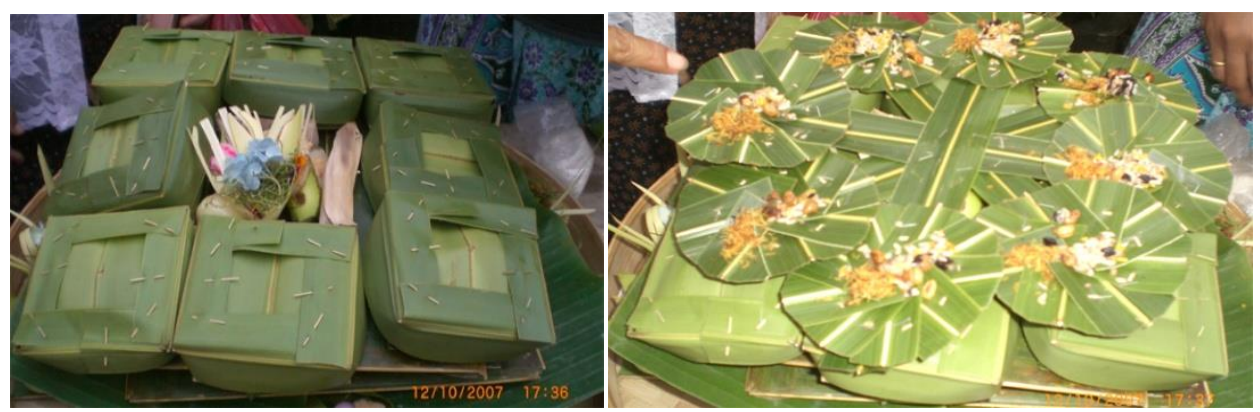

Gambar 2.14 Tetandingan pada sengkui (3)

Sumber : Pelatihan banten Br.Gemeh

- Setelah itu keben-kebenan ditutup.

- Diatas keben-kebenan diletakkan CAU DANDAN, yang diletakkan sesuai arah mata angin. (cau diiseh ke kiri)

- Cau diisi nasi sasah brumbun dan kacang saur.

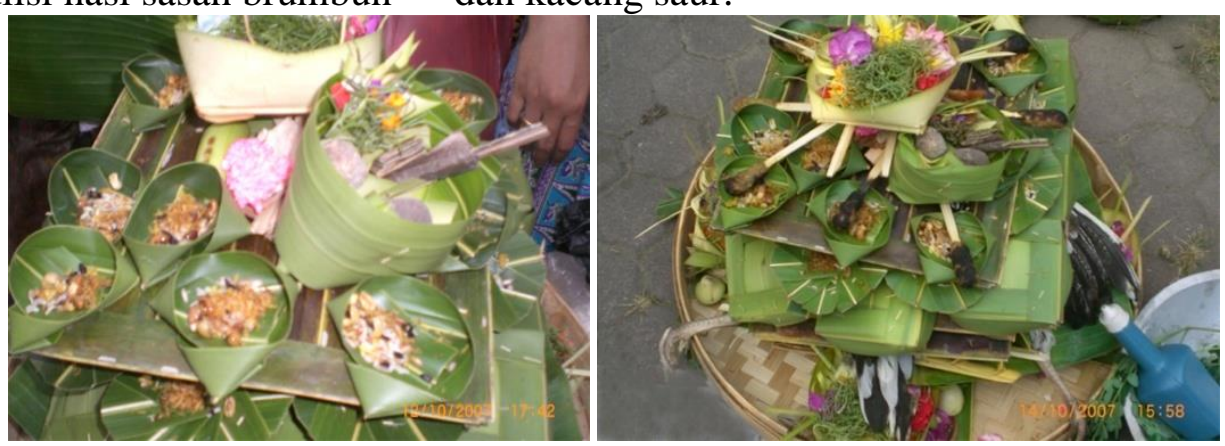

Gambar 2.14 Tetandingan Gelar sanga

Sumber : Pelatihan banten Br.Gemeh

Diatas cau dandan, disusuni taledan dengan jumlah ituk-ituk 9 bh, yg letaknya sesuai pengideran. Masing-masing ituk diisi nasi sasah brumbun dan kacang saur. Pada bagian tengah 
Jurnal Sewaka Bhakti

Lembaga Penelitian dan Pengabdian Kepada Masyarakat

Universitas Hindu Indonesia Denpasar

Volume 3, Nomor 1 Oktober 2019

ISSN: 2654-2935 (Online)

https://ejournal.unhi.ac.id/index.php/sewakabhakti

pp.10-24

diisi jaja raka-raka jangkep. Pada ituk-ituk yang mesibeh diisi eteh-eteh daksina (kecuali telor dan kelapa) dan diisi sampian plaus. Tetandingan ini bernama : Gelar Sanga. Setiap ituk-ituk yang berisi nasi sasah brumbun diisi sate lembat masing masing 1, dengan tangkai sate menghadap kedalam. Kemudian disusuni canang. Tetandingan banten caru siap brumbun selesai.
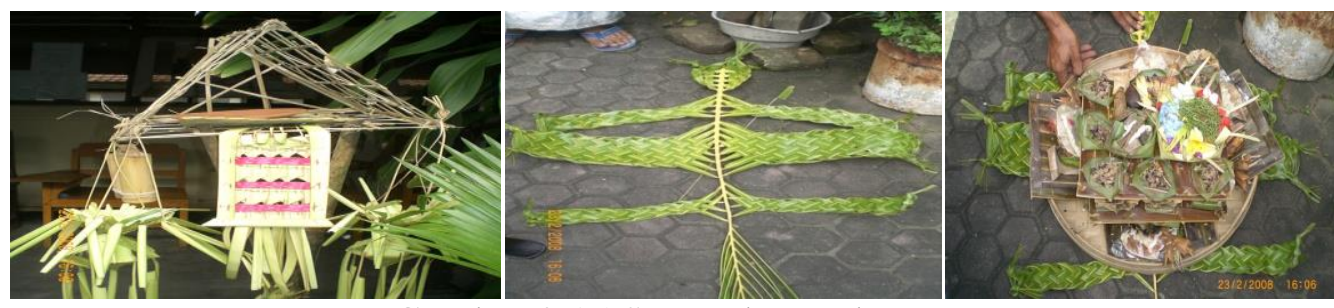

Gambar 2.15 Sanggah cucuk caru

Sumber : Pelatihan banten Br.Gemeh

Pada sanggah cucuk, digantungi sujang/cambeng (berisi arak dan berem). Isi gantunggantungan, munggah soda. Siapkan kelabang dangap-dangap, dan diatas kelabang ini diletakkan tetandingan banten caru.

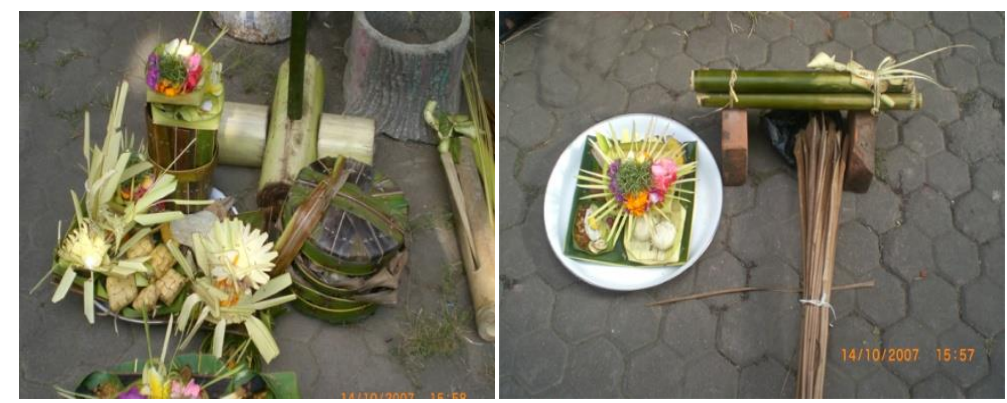

Gambar 2.16 Ulun caru

Sumber : Pelatihan banten Br.Gemeh

Pejati sebagai ulun caru, diletakkan disebelah kiri, sedangkan suci sari diletakkan sebelah kanan. Pada penimpug; bantennya soda. Saat menyalakan, posisi orangnya menghadap ke selatan.

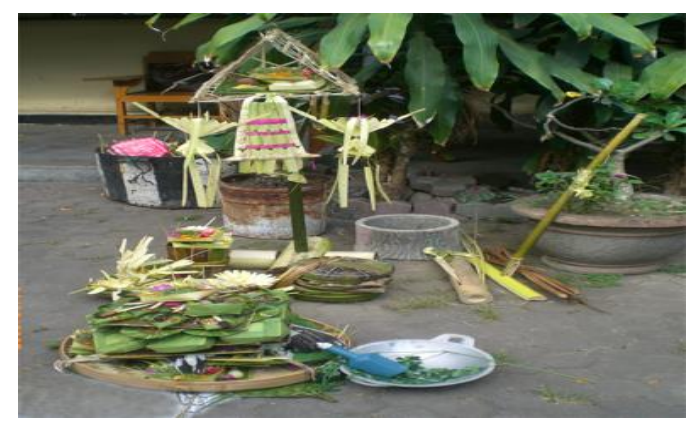

Gambar 2.17 Penempatan banten caru.

Sumber : Pelatihan banten Br.Gemeh

Seperti yang telah diuraikan sebelumnya, pemberdayaan masyarakat khususnya pada perempuan bali yang dilaksanakan di Br. Gemeh Denpasar, terjadi karena keikutsertaan ibu- 
ibu krama Br Gemeh itu sendiri, yang didampingi oleh Ibu-Ibu prejuru istri dan perangkat desa Dauh Puri Kangin Denpasar Barat. Pelatihan membuat upakara banten tersebut merupakan upaya untuk membangun kemampuan ibu-ibu krama Br. Gemeh, dengan mendorong, memotivasi, membangkitkan kesadaran akan potensi yang dimiliki dan berupaya untuk mengembangkannya menjadi tindakan nyata dan diharapkan kedepannya ibu-ibu krama Br.Gemeh mampu membuat banten sendiri dan berpeluang juga untuk dijadikan suatu usaha menjual upakara banten, mengingat upakara banten tersebut setiap saat dibutuhkan dalam upacara-upacara keagamaan hindu di Bali. Selain dari sisi kemampuan untuk membuat upakara banten dan menjadikannya sebagai peluang usaha, dengan pelatihan membuat upakara banten tersebut, ibu-ibu krama Br. Gemeh juga dapat memahami kandungan fungsi serta makna yang terkandung dalam setiap bagian-bagian pada banten tersebut.

Adapun hasil dokumentasi kegiatan pelatihan membuat upakara banten di Br.Gemeh sebagai berikut :

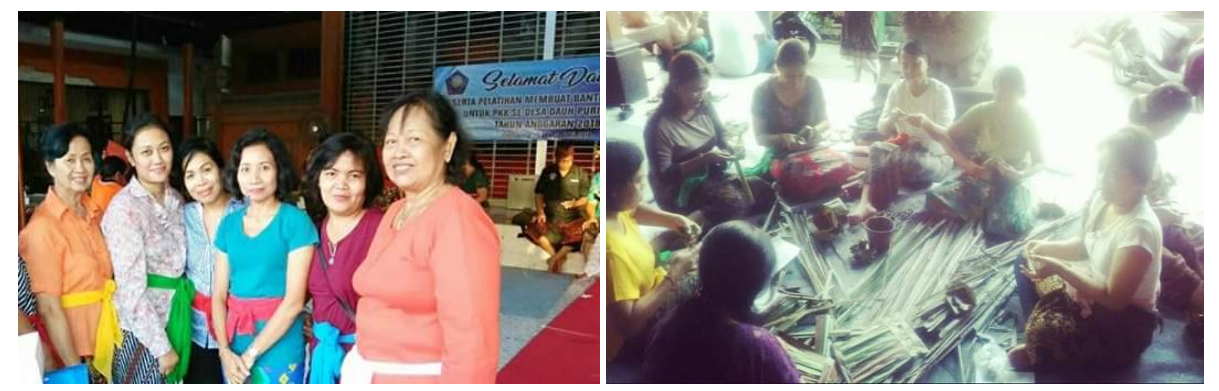

Gambar 2.17 Proses pelatihan membuat upakara banten (1)

Sumber : Dokumentasi pengabdian
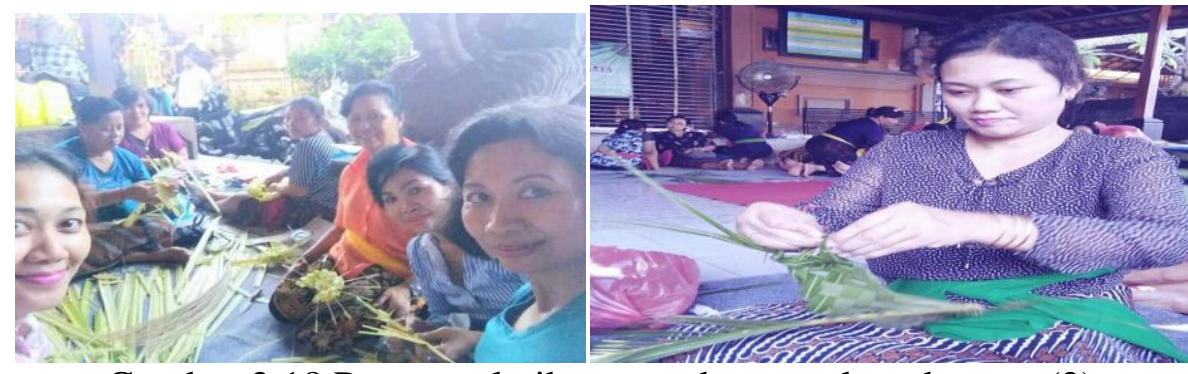

Gambar 2.18 Proses pelatihan membuat upakara banten (2)

Sumber : Dokumentasi pengabdian

Pemberdayaan perempuan Bali membuat upakara banten, bertujuan juga untuk membangkitkan kembali semangat atau spirit ngayah serta mengeratkan rasa kebersamaan dan kerukunan pada ibu-ibu krama Br.gemeh. Selain itu kegiatan tersebut merupakan suatu upaya melestarikan budaya lokal kita yaitu upakara atau banten sebagai sarana persembahyangan.

\section{PENUTUP}

Perempuan bali dengan banjar adat sebagai "tempat" atau wadah dalam melakukan berbagai macam kegiatan,mampu mewujudkan fungsi-fungsi banjar adat baik di bidang agama, adat, budaya, sosial dan ekonomi. Hal tersebut terwujud melalui pelatihan membuat upakara atau banten, yang dilaksanan ibu-ibu krama Br. Gemeh Denpasar.

\section{DAFTAR PUSTAKA}


Hadi, Y. Sumandiyo, 2006. Seni dalam Ritual Agama. Yogyakarta: Pustaka

Indriani, MN (2019) Banjar Adat As "A Place" In The Self-Actualization Of Bali Women Volume: II, Issue: II ISSN: 2581-5830. GAP GYAN -An International Peer-Reviewed Open Access Journal of Social Sciences

Kastama, I. (2013). Hukum adat sebagai alat kontrol sosial dalam kehidupanmasyarakat Hindu.TampungPenyang,11(2)RetrievedFrom http://jurnal.stahntp.ac.id/index.php/tampungpenyang/article/view/67

Noviasi, N. K. P., Waleleng, G. J., \& Tampi, J. R. (2015). Fungsi banjar adat dalam kehidupan masyarakat etnis Bali di Desa Werdhi Agung, Kecamatan Dumoga Tengah, Kabupaten Bolaang ongondow Provinsi Sulawesi Utara. Acta

Pitana, I Gde, 1994. Dinamika Masyrakat dan Kebudayaan Bali. Denpasar: Offset BP

Scott, John 2011. Sosiologi : The Key Concept. Rajawali Pers, Jakarta

Wihantari, B. (2013). Studi etnografi penanaman nilai agama hindu pada anak oleh anggota banjar Surabaya. AntroUnairDotNe, 2(1), 248-264.

https://www.kompas.com/

https://id.wikipedia.org > wiki > Pemberdayaan masyarakat. 